\title{
The Impact of Remittances on the Import Demand Function in Jordan: An ARDL Bounds Testing Approach
}

\author{
Al-Abdulrazag Bashier, PhD \\ Department of Economics, King Saud University-KSA
}

Doi: 10.19044/esj.2018.v14n10p304 URL:http://dx.doi.org/10.19044/esj.2018.v14n10p304

\begin{abstract}
The present study investigates the short- and long-run relationships between Jordan's aggregate import demand function and its macroeconomic determinants, in addition to remittances. The study employs the autoregressive distributed lagged (ARDL) model to estimate the import function over the period 1975-2016. The preliminary statistical tests, the ADF test, confirmed that none of the variables is integrated of order 2 , while the bounds testing provided evidence of the existence of a long-run equilibrium relationship between the included variables. Moreover, the diagnostic tests showed that the estimated model is free of the statistical problems. The long-run results indicated that remittances, inflation rate, and investment have a direct relationship with imports, whereas the import price index and FDI have a negative relationship. Based on these results, the study suggests that policymakers implement inflation reduction policies, increase the level of economic activities, and promote remittances inflows since they are mostly directed to investment.
\end{abstract}

Keywords: Remittances, imports, ARDL, Jordan, cointegration

\section{Introduction}

According to the geographical distribution of Jordanian imports, it is clear that China, Saudi Arabia, the United States of America, Germany, the United Arab Emirates, and Italy are the major market sources of imports, which constitute of about 46.6 percent of total imports in 2016 and around 46.7 percent in 2015 (CBJ, Annual Report, 2017, PP: 70). In terms of the share of imports by commodity in 2016 , the share of crude materials and the intermediate goods make up $47.8 \%$ of total imports, while the share of consumer goods was about $34.6 \%$ and the share of capital was $16 \%$. Hence, as these imports are very vital for economic growth, it is crucial to analyze the determinants of the import demand function in Jordan; moreover, the analysis 
is crucial for policymakers in many areas, especially with regards to trade deficit (Yi-Hsien, 2012).

The objective of this study is to estimate the import demand function for Jordan by using the most modern estimation methods as well as recent data. Analyzing the import demand function is vital to any country, especially in terms of trade balance status. Among many factors affecting imports is the flow of workers' remittances to their home countries. The concern with this factor stems from its impact on the consumption of durable and non-durable imported goods. This effect is reflected in the trade balance and later in the balance of payments of the home country. Yet, to the author's best knowledge, few existing research studies have examined the role of remittances in determining the import demand function in Jordan. For example, applying the ARDL and the bounds testing approach to cointegration over the period 19802015, Mugableh (2017) found that income has positive and significant impacts, while relative prices exert negative impacts on Jordan's imports; moreover, the long-run elasticities are greater than unity. Ziad (2014) estimated the price and income elasticities of the import demand function for Jordan over the period 1980-2012 by employing the Johansen cointegration approach. He found that income and prices elasticities of imports are greater than unity. Adel and Othman (2013) estimated the import demand function for Jordan over the period 1976-2008 using multiple linear regression models. The finding indicated a direct relation between imports and GDP, CPI, and REM, whereas it is negative with relative prices and exchange rate and, in addition, they are all inelastic. Al-Hazaimeh et al. (2011) found that GDP, investment, and exports are major determinants of the import demand function for Jordan. They employed the multiple regression method for the period 1976-2008. Kreishan (2007) estimated the import demand function for Jordan over the period 1972-2004 employing the Johansen cointegration approach. The finding indicated that the aggregate import volume is price and income inelastic. As for remittances, the results show they have a positive significant impact on aggregate imports and act as a source for financing imports. Majeed (2007) estimated the traditional import demand function for Jordan over the period 1980-2004 using the dynamic OLS method. His findings revealed that relative price and income elasticities were -0.55 and 0.84 , respectively. Only Adel and Othman (2013) and Kreishan (2007) investigated the role of remittances in the import function.

The current paper contributes the following. First, it analyzes the influence of on Jordan's import demand function. Second, it uses one of the most recent modern estimation techniques, the ARDL approach, which avoids the problem of spurious regression, statistical problems, and estimation problems. Third, it utilizes up-to-date and longer time series data. 
The rest of the paper is organized as follows. Section 2 presents a review of the literature on import demand function. Section 3 illustrates the econometric model specification and data. Section 4 analyzes the estimation results. Finally, Section 5 is the conclusion and suggests some policy implementation remarks.

\section{Literature Review}

The import demand function has been estimated by numerous applied research studies for both developed and developing countries. A large number of economic and non-economic variables were included in the model specification of the determinants of import demand function. The majority of the applied research estimates the traditional import demand function using economic activity, relative prices, real effective exchange rate, final consumption, FDI, foreign reserves, exports, and financial development among other macroeconomic variables. For example, Abdulsalam (2015) for Libya; Aldakhil and Nourah (2002) for Saudi Arabia, Al-Khulaifi (2013) for Qatar, N'guessan and Yue (2010) for Cote D'Ivoire, Khurram and Syed (2012) for Pakistan, Nazif and Jaehyuk (2015) for Turkey, Emmanuel and Mooya (2013) for Namibia, Ibrahim and Ahmed (2017) for Sudan, BigBen (2016) for Nigeria, Zhou and Dube (2011) for CIBs countries, Sulaiman and Saba (2016), and AbdulRashid and Tayyaba (2010) for Pakistan. All the above-mentioned studies use different estimations methods indicating a positive association between imports and income, and a negative association with relative prices and real effective exchange rate.

Following the scope of the current study, this section reviews the most recent studies to select the appropriate and relevant factors to estimate the import demand function for Jordan, whereas the emphasis is on the impact of remittances on imports.

Chantha et al. (2018) estimated the long-run and short-run import demand function for Cambodia over the period 1993-2015 by employing the ARDL model. Their empirical finding showed that inflation and the exchange rate have negative impacts, whereas exports have a positive impact. Using the standard OLS regression approach over the period 1988-2015 for Saudi Arabia, Abdullah Almounsor (2017) found that GDP, government expenditures, private consumption, and investment have positive and significant impacts, while the real effective exchange rate exerts a negative impact. Applying the ARDL model to data over the period 1973-2013 for Pakistan, Sulaiman and Saba (2016) found that consumption, exports, and investment have a positive significant impact; final consumption expenditure, and government consumption expenditure showed negative and significant impact. Ahmed et al. (2014) examined the short-run and long-run relationships between imported goods and workers' remittances in Pakistan over the period 
2008-2012 employing Johansen cointegration and Granger causality. The finding showed a positive and significant impact of remittances on imports. However, Granger causality indicated a unidirectional causality runs from imports to remittances. M. Sayed (2014), applying the vector error correction (VECM) model to annual data over the period 1991-2011 for Egypt, found that remittances exert a positive and significant impact on imports as indicated by the unidirectional causality runs from remittances to imports. Dewan et al. (2013) applied the Johansen cointegration approach to monthly data over the period 2005-2011 for Bangladesh. The finding showed that remittances have an insignificant impact on imported goods, and a unidirectional causality runs from imports to remittances. Guna (2013), applying cointegration and a VECM model to monthly data over the period 2001-2011 for Nepal, found that remittances exert a significant positive impact on imported merchandised goods and services, where the unidirectional causality runs from remittances to imports. Karan and Sanjanya (2013), employing the OLS method and Granger causality test for Nepal over the period 2001-2009, found that remittances Granger-cause imports. Soana and Olta (2013) adapted a VECM model using monthly data over the period 1999-2011 for Albania. The finding showed that GDP and remittances exert positive impacts on imports, while real effective exchange rate and average tariffs have negative impacts. YiHsien (2012) applied the ARDL approach for data over the period 1992-2011 for China. The finding indicated that GDP has a significant positive impact, whereas real effective exchange rate was negative and insignificant. Using the OLS method, Munir et al. (2007) estimated the import function for Pakistan. The finding showed that remittances and GDP have positive and significant impacts on imports, while real effective exchange rate was negative. Khair and Nazakat (2005) applied the OLS method using quarterly data over the period 1975-2004 in Pakistan. The findings indicated that remittances have a positive and significant impact on imports.

The surveyed literature pointed out the positive impact of remittances on aggregate imports and that the impact size differs among receiving countries depending on the estimation methods and data span. Table (1) summarizes the findings of the surveyed literature. 
Table (1): Most Frequent Used Variables in the Literature Survey

\begin{tabular}{|c|c|c|c|}
\hline Variable & Positive & Negative & Insignificant \\
\hline GDP & $\begin{array}{l}\text { Yi-Hsien (2012), } \\
\text { Zhou and Dube (2011), } \\
\text { Soana and Olta (2013), } \\
\text { Munir et al. (2007), Soana } \\
\text { and Olta (2013), } \\
\text { AbdulRashid and Tayyaba } \\
\text { (2010), Ibrahim and Ahmed } \\
\text { (2017), Khurram and Syed } \\
\text { (2012), } \\
\text { Aldakhil and Nourah (2002) }\end{array}$ & & BigBen (2016) \\
\hline $\mathbf{R P}$ & $\begin{array}{l}\text { Yi-Hsien (2012) } \\
\text { Zhou and Dube } \\
\text { Karan and Sanjanya (2013) } \\
\text { Emmanuel and Mooya (2013) } \\
\text { Khurram and Syed (2012) }\end{array}$ & $\begin{array}{l}\text { Chantha et al. (2018), } \\
\text { Nazif and Jaehyuk } \\
(2015), \quad \text { AbdulRashid } \\
\text { and Tayyaba (2010), } \\
\text { N'guessan and Yue } \\
(2010) \text {. }\end{array}$ & $\begin{array}{l}\text { Dube. (2011), Ibrahim and } \\
\text { Ahmed (2017), BigBen (2016) }\end{array}$ \\
\hline REMIT & $\begin{array}{l}\text { Soana and Olta (2013) } \\
\text { Ahmed et al. (2014 } \\
\text { Karan and Sanjanya (2013) } \\
\text { Dewan et al. (2013) } \\
\text { M. Sayed (2014) } \\
\text { Gunna (2013) } \\
\text { Khair and Nazakat (2005) } \\
\text { Munir et al. (2007) } \\
\text { Soana and Olta (2013) }\end{array}$ & & BigBen (2016) \\
\hline REER & $\begin{array}{l}\text { Abdulah (2017) } \\
\text { Munir et al. (2007) } \\
\text { Soana and Olta (2013) } \\
\end{array}$ & $\begin{array}{l}\text { Soana and Olta (2013) } \\
\text { Chantha et al. (2018) } \\
\text { Yi-Hsien (2012) }\end{array}$ & Ibrahim and Ahmed (2017) \\
\hline FDI & & & $\begin{array}{l}\text { Chantha et al. (2018) NS } \\
\text { Sulaiman and Saba (2016) }\end{array}$ \\
\hline CONS & $\begin{array}{l}\text { Karan and Sanjanya (2013) } \\
\text { Sulaiman and Saba (2016) } \\
\text { Emmanuel and Mooya (2013) } \\
\text { Nazif and Jaehyuk. (2015) } \\
\text { N'guessan and Yue 2010 }\end{array}$ & & Chantha et al. (2018) \\
\hline $\begin{array}{l}\text { INVEST- } \\
\text { MENT }\end{array}$ & $\begin{array}{l}\text { Karan and Sanjanya (2013) } \\
\text { Sulaiman and Saba (2016) } \\
\text { Emmanuel and Mooya (2013) } \\
\text { Nazif and Jaehyuk. (2015) } \\
\text { N'guessan and Yue 2010 }\end{array}$ & & \\
\hline $\begin{array}{l}\text { EXPORT } \\
\text { S }\end{array}$ & $\begin{array}{l}\text { Sulaiman and Saba (2016) } \\
\text { Nazif and Jaehyuk (2015) } \\
\text { N'guessan, and Yue. 2010 }\end{array}$ & & $\begin{array}{l}\text { Emmanuel and Mooya (2013) (- } \\
\text { Al-Khulaifi. (2013) }\end{array}$ \\
\hline $\begin{array}{l}\text { INFLATI } \\
\text { ON }\end{array}$ & Aldakhil and Nourah (2002) & & \\
\hline
\end{tabular}




\section{Methodology: Data and Model Specification}

This section addresses the econometric methodology and the data sources adapted in the current study to estimate the import demand function in Jordan. Moreover, it illustrates the model specification in terms of the variables to be included in the model.

\subsection{Model Specification}

Chantha et al (2018) indicated that the traditional import demand function is based on the imperfect substitution theory, which focused on the role of the importing country's income, the price the imported goods, and the import substitute goods. The current study utilizes the previous reviewed literature which shows different forms of the import demand function based on single-country, groups-countries, and various econometric approaches to estimate the import demand function to choose the relevant variables relevant to Jordan's economy case. Accordingly, the functional form of the import demand function in Jordan is as follows:

$$
\mathrm{IM}=\mathrm{f}(\mathrm{Y}, \mathrm{CPI}, \mathrm{IPI}, \mathrm{REM}, \mathrm{FDI}, \mathrm{GFCF})
$$

Where IM is the import demand; $Y$ is the real gross domestic product measured at constant prices $(\$ 2005=100)$; REM is the volume of formal remittances; CPI is the consumer price index $(2005=100)$ proxy for the inflation rate; IPI is the import price index; GFCF is gross fixed capital formation proxy for investment; and FDI is the stock of foreign direct investment. It is expected that the real GDP to exert positive impact on imports, since the increase in the real GDP stimulates private consumption of imports. As for the rate of inflation, the model expects a positive impact on imports; as domestic inflation rate increase, people shift to imports which are cheaper. Remittances are expected to have positive impact on imports. Remittances can be used either for consumption or investment activities, which increases the demand for goods including imported ones. The import price index is expected to have negative impact; while GFCF is expected to exert positive impact. FDI can have negative or positive impact on imports. The long-run import demand function for Jordan in is expressed in logarithmic form.

\subsection{Data Description}

The required data for the estimation process were obtained from various sources, the UNTCAD, the Central Bank of Jordan publications, and the World Development Indicators (WDI).

\subsection{Econometric Analysis: ARDL bounds testing}

The objective of the current study is to estimate the long-run and shortrun relationships between the variables of the import demand function for 
Jordan over the period 1975-2016. There is numerous applied works investigating the long-run relationship between import demand and suggested determinants, as mentioned in literature review earlier. Specifically for Jordan, Mugableh (2017), Ziad (2014), Adel and Othman (2013), Al-Hazaimeh et al. (2011), Kreishan (2007), Majeed (2007) investigated the import demand function. However, only Adel and Othman (2013) and Kreishan (2007) included remittances in the model.

The study employs one of the most widely used econometric methods in time-series analysis, the autoregressive distributed lagged (ARLD) model bounds testing approach to cointegration introduced by Pesaran, et al. (2001) to estimate the long-run and short-run relationships between Jordan's aggregate import and a set of explanatory variables. The analysis involves examining the degree of integration of the series via the unit root test, the cointegration test to examine the existence of long-run equilibrium relationships, and the Granger causality test within a VECM framework. There are many advantages for adapting such approaches over other procedures proposed by Johansen (1990, 1991) and Engle (1987). First, it is suitable irrespective of the order of integration of the variables; either I(0) or I(1), as long as it is not $\mathrm{I}(2)$; therefore, this would avoid the stationarity problems (Zhou and Dube, 2011). Second, in the case of using small samples, the approach is more appropriate than other cointegration approaches.

Generally, the first step is to test for the stationarity properties of all variables before proceeding with the ARDL bounds testing to ensure that all time series are either I( 0$)$ or I(1) but not I(2). Therefore, the ARDL bounds testing approach is employed to estimate equation (2) using OLS to test for the presence of a long-run equilibrium relationship among the variables

$$
\begin{aligned}
\Delta I M=\alpha_{0}+\sum_{i=1}^{n} & \alpha_{1 i} \Delta I M_{t-1} \\
& +\sum_{j=0}^{s} \beta_{2 i} \Delta Y_{t-i} \\
& +\sum_{j=0}^{p} \beta_{3 i} \Delta C P I_{t-j} \\
& +\sum_{j=0}^{p} \beta_{4 i} \Delta R E M_{t-j}+\sum_{j=0}^{p} \beta_{5 i} \Delta I P I_{t-j}+\sum_{j=0}^{p} \beta_{6 i} \Delta G F C F_{t-j} \\
& +\sum_{j=0}^{p} \beta_{7 i} \Delta F D I_{t-j}+\delta_{1} I M_{t-1}+\delta_{2} \mathrm{Y}_{t-1}+\delta_{3} C P I_{t-1} \\
& +\delta_{4} R E M_{t-1}+\delta_{5} I P I_{t-1}+\delta_{6} G F C F_{t-1}+\delta_{7} F D I_{t-1}+\varepsilon_{t}
\end{aligned}
$$


Where $\Delta$ is the first different operator; $\alpha_{0}$ is the intercept; $p$ is the maximum lag length; $i$ is the number of lags; $\beta(i, p=1, \ldots \ldots, 7)$ indicates the short run coefficients; $\delta(i, p=1, \ldots \ldots, 7)$ shows the long-run coefficients; and $\left(\varepsilon_{t}\right)$ is the white noise error term.

The hypothesis to test the presence of long-run relationship among the model variables is set as following:

$$
\begin{gathered}
\mathrm{H}_{0}: \delta_{1}=\delta_{2}=\delta_{3}=\ldots=\delta_{7}=0 \\
\mathrm{H}_{1}: \delta_{1} \neq \delta_{2} \neq \delta_{3} \neq \neq \delta_{7} \neq 0 .
\end{gathered}
$$

The null hypothesis was tested by performing an F-test for the joint significance of the coefficients of the lagged levels of the variables against the critical values introduced by Narayan (2005). If the F-statistic is greater than the upper bound critical value, then the null hypothesis of no cointegration can be rejected.. Conversely, if the F-statistic is less than the lower bound critical value, then we cannot reject the null hypothesis of no cointegration. However,, when the f-statistic is within the two bounds, then the test is inconclusive. The optimal lag-length of the ARDL model is selected using the Akaike information criteria (AIC).

If there is evidence on the existence of long-run relationship between import demand and its determinants, the next step is to examine the short-run dynamic coefficients and the $E C T_{t-1}$ coefficient. The $E C T_{t-1}$ coefficient measures the speed of adjustment from short-run towards long-run equilibrium among variables (Chantha et al., 2018). Then, the short-run relationship for Jordan's import demand can be expressed as following in equation (3):

$$
\begin{aligned}
& \Delta I M=\alpha_{0}+\sum_{i=1}^{n} \alpha_{1 i} \Delta I M_{t-1}+\sum_{j=0}^{p} \alpha_{2 i} \Delta Y_{t-j} \\
&+\sum_{j=0}^{s} \alpha_{3 i} \Delta C P I_{t-i} \\
&+\sum_{j=0}^{p} \alpha_{4 i} \Delta I P I_{t-j} \\
&+\sum_{J-0}^{P} \alpha_{5 i} \Delta R E M_{t-j}+\sum_{J-0}^{P} \alpha_{6 i} \Delta F D I_{t-j} \\
&+\sum_{J-0}^{P} \alpha_{7 i} \Delta G F C F_{t-j}+\lambda_{1} E C T_{t-1}+\varepsilon_{t}
\end{aligned}
$$

Where $\Delta$ is the first different operator; $\alpha_{0}$ is the constant; $p$ is the maximum lag length; $i$ is the number of lags; $\alpha(J, i=1, \ldots \ldots, 7)$ indicates the 
short run coefficients; and $\lambda$ is the coefficient of the lagged error term, $E C T_{t-1}$, and it should be negative.

\subsection{Diagnostic stability tests}

Diagnostic statistics are adapted to ensure the validity of the estimation results. For that reason, the Lagrange multiplier (LM) test of residual serial correlation, Ramsey's RESET test for functional form misspecification, normality test, and White's test for heteroscedasticity are employed.. To test for structural changes, the stability of the estimated short-run and long-run coefficients was examined by employing the cumulative sum of recursive residuals (CUSUM) and cumulative sum of squares of recursive residuals (CUSUMSQ) tests proposed by Brown et al. (1975).

\section{Estimation results and discussion}

\subsection{Unit root test (Stationarity test)}

According to Pesaran et al. (2001), the first step before proceeding with the ARDL bounds testing is the determination of the order of integration to ensure that the time series are either $\mathrm{I}(0)$ or $\mathrm{I}(1)$ but not $\mathrm{I}(2)$. Table (2) reports the results of the augmented Dickey-Fuller (1979) unit roots test. The ADF test results indicate that all variables are stationary at their firstdifferenced integrated of order one, I(1).

Table 2: Results of unit roots tests

\begin{tabular}{|c|c|c|c|c|c|c|}
\hline \multirow{2}{*}{ Variable } & \multicolumn{3}{|c|}{ ADF results (level) } & \multicolumn{3}{c|}{ ADF results (differenced) } \\
\cline { 2 - 7 } & Constant & Constant \& Trend & None & Constant & Constant \& Trend & None \\
\hline LIM & $-0.3(0)$ & $-2.28(1)$ & $1.56(6)$ & $-4.26(0)$ & $-4.3(0)$ & $-4.12(0)$ \\
\hline IPI & $0.14(0)$ & $-2.26(3)$ & $1.69(0)$ & $-4.73(0)$ & $-4.86(0)$ & $-1.96(2)$ \\
\hline LFDI & $-1.37(0)$ & $-2.02(3)$ & $-0.8(0)$ & $-5.13(0)$ & $-5.028(0)$ & $-5.19(0)$ \\
\hline LY & $-1.49(1)$ & $-1.83((1)$ & $2.56(1)$ & $-2.89(6)$ & $-3.97(0)$ & $-2.01(0)$ \\
\hline CPI & $0.89(0)$ & $-2.45(2)$ & $5.74(6)$ & $-4.45(0)$ & $-4.53(0)$ & $-1.73(1)$ \\
\hline LRMIT & $-1.24(0)$ & $-3.92(4)$ & $2.97(7)$ & $-3.87(6)$ & $-3.89(6)$ & $-4.9(0)$ \\
\hline GFCF & $-3.69(0)$ & $-3.92(6)$ & $-1.66(0)$ & $-5.25(9)$ & $-5.43(0)$ & $-5.48(9)$ \\
\hline \multicolumn{7}{|c}{$(*),(* *),(* * *)$ significant at $1 \%, 5 \%$, and $10 \%$ respectively, lags numbers are in } \\
Parenthesis
\end{tabular}

Adapting the ADF results moves the analysis to the next step, which is testing for the existence of long-run equilibrium relationship among variables.

\subsection{Diagnostic and stability tests}

The statistical tests of the ARDL $(2,3,2,0,3,3,1)$ estimation results are necessary to ensure that the model is free of statistical problems. Diagnostic tests for serial correlation, functional form, normality, and heteroscedasticity have been conducted and the results are presented in Table (4). The LM Serial correlation test, in addition to DW test (2.16) indicates that 
the model does not suffer from the problem as it is shown by the insignificant value of LM F-statistic test (1.15), therefore, one may accept the hypothesis of no serial correlation. Additionally, the Breusch-Pagan-Godfrey heteroscedasticity test of the insignificant F-statistics test (0.42) indicates the absence of this problem; and Ramsey's RESET of Functional form test is insignificant. Finally, Jaque-Bera's normality test statistic is insignificant (0.809), revealing that error terms are normally distributed. Based on these test results, the model is free of econometric problems; and the estimation results are valid for meaningful interpretation.

\begin{tabular}{|l|c|c|}
\multicolumn{1}{c|}{ Table (4): Diagnostic tests } \\
\hline Test & F-statistics & P-Value. \\
\hline Serial Correlation & 2.8 & 0.108 \\
\hline Functional Form & 066 & 0.59 \\
\hline Normality & 0.70 & 0.702 \\
\hline heteroscedasticity & 0.42 & 0.6 \\
\hline
\end{tabular}

The study applies the cumulative sum of recursive residuals (CUSUM) and the CUSUM of the square (CUSUMSQ) to ensure the parameters' stability. Figure (1) shows that the plots of the CUSUM and CUSUMSQ statistic fall with the critical bands of the 5 percent confidence interval of parameter stability. Therefore, the results confirm the existence of the stability in the parameters over the study period.

Figure (1): The stability test results
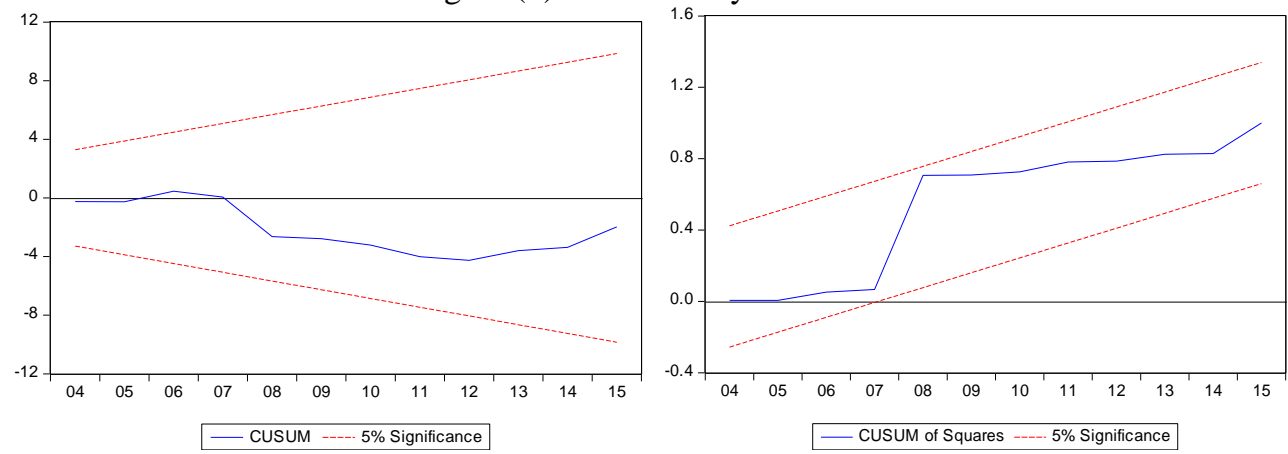

\subsection{Cointegration results}

The next step is to examine the existence of the long-run relationships between model variables by applying the bounds testing approach to cointegration. As Table (5) shows, the calculated F-statistics of 4.02 is greater than the upper bound critical value of 4.01 provided by Pesaran (2001) at the 5 percent level, and hence, one can reject the null hypothesis of no cointegration. The result from bounds testing approach to cointegration provides evidence on the long-run relationship between the variables. 


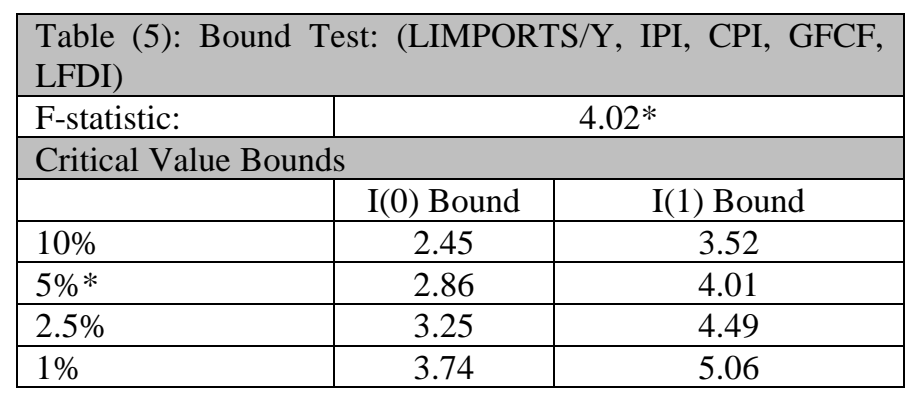

\subsection{Short-run estimation results}

Based on the cointegration results, we can estimate the VECM model for the cointegrated equation. Table (6) contains the short-run estimation results of the ARDL $(2,3,2,0,3,3,1)$ model. It indicates that the majority of the first-differenced of all variables as well as their lagged periods are significant in the short-run. These results indicate that these variables have a short-run effect on the import demand function in Jordan.

\begin{tabular}{|l|c|c|c|c|}
\hline \multicolumn{5}{|l|}{ Table (6): Short-run Cointegrating Results for Selected Model: ARDL(2, 3, 2, $0,3,3,1)$} \\
\hline Variable & Coefficient & Std. Error & t-Statistic & Prob. \\
\hline DLOG(IM(-1)) & 0.412124 & 0.237354 & 1.736326 & 0.1081 \\
\hline DLOG(Y) & 3.066670 & 0.677223 & 4.528300 & 0.0007 \\
\hline DLOG(Y(-1)) & 1.953987 & 0.913596 & 2.138786 & 0.0537 \\
\hline DLOG(Y(-2)) & -1.915532 & 0.302432 & -6.333766 & 0.0000 \\
\hline DLOG(REM) & 0.227843 & 0.143270 & 1.590309 & 0.1378 \\
\hline DLOG(REM (-1)) & 0.295041 & 0.174395 & 1.691798 & 0.1165 \\
\hline D(CPI) & 0.012202 & 0.003128 & 3.900847 & 0.0021 \\
\hline D(IPI) & 0.002770 & 0.000864 & 3.205518 & 0.0076 \\
\hline D(IPI(-1)) & 0.000813 & 0.000900 & 0.903085 & 0.3843 \\
\hline D(IPI(-2)) & 0.001459 & 0.000314 & 4.650469 & 0.0006 \\
\hline DLOG(GFCF) & 0.236315 & 0.159154 & 1.484821 & 0.1634 \\
\hline DLOG(GFCF(-1)) & -0.434197 & 0.258588 & -1.679104 & 0.1190 \\
\hline DLOG(GFCF(-2)) & 0.453068 & 0.152968 & 2.961846 & 0.0119 \\
\hline DLOG(FDI) & -0.011923 & 0.016648 & -0.716191 & 0.4876 \\
\hline CointEq(-1) & -1.557629 & 0.226066 & -6.890148 & 0.0000 \\
\hline CointEq = LOG(IMPORTS) - (1.4024*LOG(Y) + 0.2186*LOG(REMIT) + \\
\hline $0.0078 *$ CPI -0.0006*IPI + 0.4968*LOG(GFCF) -0.0337*LOG(FDI) -8.2727) \\
\hline
\end{tabular}

The important feature of these results is the error correction term which turned out to be negative and significant at the $1 \%$ level. This result provides evidence of the presence of a long-run causality runs from explanatory variables to (IM). The coefficient of the error correction term is $(-1.56)$ indicating that $1.56 \%$ of short-run shock is corrected in each year, and it takes less than a year to restore long-run equilibrium. 
Table 7 reports the long-run estimation results of ARDL (2, 3, 2, 0, 3, $3,1)$. The table shows that the economic activity (GDP) is positive and statistically significant at the 1 percent level with elasticity equal to $1.4 \%$. The result indicates that a $1 \%$ increase in the GDP increases imports by $1.4 \%$. The result of economic growth or economics activity is in line with Yi-Hsien (2012) for China, Zhou and Dube (2011) for CIBs, Soana and Olta (2013) for Albania, Munir et al. (2007) for Pakistan, Abdul Rashid and Tayyaba (2010) for Pakistan, Ibrahim and Ahmed (2017) for Sudan, Khurram and Syed (2012) for Pakistan, and Aldakhil and Nourah (2002) for Saudi Arabia who found a significant positive impact of GDP (income) on the import demand function. On the other hand, in the Nigerian case, BigBen (2016) found an insignificant impact of GDP. As for Jordan, Mugableh (2017), Ziad (2014), Adel and Othman (2013), and Al-Hazaimeh (2011) found a direct relation between GDP and imports. The results indicated that remittances have a significant positive impact on imports, where the elasticity of imports with respect to remittances is inelastic. The elasticity is 0.218 , hence, an increase of remittances by $1 \%$ leads to an increase in imports by $0.218 \%$. The remittances result is in line with Soana and Olta (2013) for Albania, Ahmed et al. (2014) for Pakistan, Karan and Sanjanya (2013) and Dewan et al. (2013) for Bangladesh, M. Sayed (2014) for Egypt, Gunna (2013) for Nepal, Khair and Nazakat (2005) and Munir et al. (2007) for Pakistan, Adel and Othman (2013) and Kreishan (2007) for Jordan, who all found a significant positive impact; whereas BigBen (2016) found insignificant impact of remittances on imports for Nigeria. The price level exerts a very low positive and significant impact and is inelastic as well. An increase in the price index by $1 \%$ leads to a $0.007 \%$ increase in imports. The price index result is in line with Aldakhil and Nourah (2002). The import price index has a negative but insignificant impact on imports; in addition, the influence is very weak (-0.0006). Therefore, a $1 \%$ increase in the imports price index leads to a $0.0006 \%$ decrease in imports. The import price index result is in line with Aldakhil and Nourah (2002) for Saudi Arabia. The investment level measured as the gross fixed capital formation (GFCF) has a significant positive impact on imports, and it is inelastic. A $1 \%$ increase in GFCF increases imports by a $0.49 \%$. This result is in line with Karan and Sanjanya (2013) for Nepal, Sulaiman and Saba (2016) for Pakistan, Emmanuel and Mooya (2013) for Namibia, Nazif and Jaehyuk (2015) for Turkey, and N'guessan and Yue (2010) for Cote D'Ivoire, whose results supported the significant positive impact of investment on imports. 


\begin{tabular}{|l|l|l|l|l|}
\hline \multicolumn{5}{|c|}{ Table (7): Long Run Coefficients } \\
\hline Variable & Coefficient & Std. Error & t-Statistic & Prob. \\
\hline & & & & \\
\hline LOG(Y) & 1.402447 & 0.177544 & 7.899148 & 0.0000 \\
\hline LOG(REM) & 0.218553 & 0.090634 & 2.411372 & 0.0328 \\
\hline CPI & 0.007833 & 0.001601 & 4.893540 & 0.0004 \\
\hline IPI & -0.000649 & 0.000490 & -1.325146 & 0.2098 \\
\hline LOG(GFCF) & 0.496825 & 0.083142 & 5.975650 & 0.0001 \\
\hline LOG(FDI) & -0.033711 & 0.012871 & -2.619108 & 0.0224 \\
\hline C & -8.272741 & 1.475380 & -5.607195 & 0.0001 \\
\hline
\end{tabular}

Finally, the foreign direct investment (FDI) has a significant negative impact on imports as well as inelastic. A $1 \%$ increase in FDI decreases imports by $0.034 \%$. This result contradicts the insignificant impact found by Chantha et al. (2018) for Cambodia and Sulaiman and Saba (2016) for Pakistan.

\section{Conclusion and Policy Implication}

The present study is an attempt to examine the impact of remittances along with other macroeconomic variables on the imports of Jordan over the period 1976-2016. It adapted the most recent estimation technique, the autoregressive distributed lagged (ARDL) model, which has many advantages over other techniques. The estimation results support the existence of the longrun equilibrium relationship between them. The ECM coefficient is negative and significant indicating that the causality runs from the explanatory variables to imports and, in addition, the magnitude of the coefficient (1.56) shows that it takes less than one year to restore the long-run equilibrium after a short-run shock. The long-run results show a significant positive influence of remittances, level of income (economic growth), investment, and price level on imports; meanwhile, the import price index and FDI have negative and significant impacts on imports. In addition, all variables are inelastic except remittances. This pointed out the important role of remittances on stimulating imports, and the ultimate effect depends on the type of imported goodsdurable (capital) or non-durable (consumption). The current study suggests some policy recommendations that are expected to help policymakers adapt some policy measures to reduce the trade balance consequences. First, reducing the price level would help reduce imports and increase exports, and hence, improve trade balance. Second, increasing the level of economic activities and economic growth would increase capital goods for investment.

The literature on the import demand function contains a considerable number of macroeconomic variables that are expected to influence the import demand function. The present study utilized selected macroeconomic variables that are thought to be crucial to import demand function. Therefore, the study recommends that future research on the import demand function by 
investigating new variables, different estimation method, and data to compare the present results

\section{References:}

1. Abdullah, Hussein Almounsor (2017). Diagnostic Analysis of Imports Demand Behavior in Saudi Arabia: Journal of Economics and Development Studies, 5(2), 47-56.

2. AbdulRashid, and Tayyaba Razzaq (2010). Estimating ImportDemand Function in ARDL Framework: The Case of Pakistan: MPRA Paper No. 23702.

3. Abdusalam, F. Yahia (2015). An Econometric Estimation and Evaluation of the Import Function in the Libyan Economy: Journal of Economics, Business, and Management, 3(10), 994-998.

4. Adel, A. Haddaw, Mahdy. S. Othman (2013). The Impact of Some Economic Factors on Imports in Jordan: Research Journal of Finance and Accounting, 4(15), 1-10.

5. Ahmed, R. Raheem; Parmar V.; and Ahmad N. (2014). Causal Relationship between Worker's Remittances and Imports in Pakistan: European Journal of Scientific Research, 119 (3), 327-336.

6. Aldakhil, Khalid and Nourah Al-Yousef (2002). Aggregate Import Demand Function for Saudi Arabia: An Error Correction Approach: Journal of Econo2mic \& Administrative Sciences, 18(1), 83-100.

7. Al-Hazaimeh, Adeeb, Khalil Al-Hyari, and Marwan AL-Nasour (2011). Determinants of Aggregate Imports in Jordan: Empirical Evidence (1976-2008): Journal of Economic Development, Management, IT, Finance and Marketing, 3(1), 18-38.

8. Al-Khulaifi, Abdulla S. (2013). Exports and Imports in Qatar: Evidence from Cointegration and Error Correction Model: Asian Economic and Financial Review, 3(9), 1122-1133.

9. BigBen, Chukwuman Ogbonna (2016). Estimating Aggregate Import-Demand Function for Nigeria Revisited: Journal of Business and Management, 18(3), 64-72.

10. Brown, R.L., Durbin, J., Evans, J.M. (1975). Techniques for Testing the Constancy of Regression Relations Over Time: Journal of the Royal Statistical Society, 37, 149-163.

11. Central Bank of Jordan (2017). Annual report, PP: 70.

12. Chantha Hor, Kakda Keo, Chutima Suttiprapa (2018). An Empirical Analysis of Cambodia's Import Demand Function: Journal of Management, Economics, and Industrial Organization, 2(1), 1-12.

13. Dewan, M.-Al-Mukit; A. Z. M. Shafiullah; Anamul H. Sajib (2013). Determination of Causality between Remittance and Import: 
Evidence from Bangladesh". International Journal of Business and Social Research (IJBSR), 3(3), 55-62.

14. Dickey, D. A., and Fuller, W.A. (1979). Distribution of the Estimators for Autoregressive Time Series with a Unit Root: Journal of the American Statistical Association, 74, 427-431.

15. Emmanuel, Ziramba1 and Mooya Bauku (2013). An Empirical Analysis of Aggregate Import Demand and Expenditure Components in Namibia: Int. J. Eco. Res., 4(4), 39 - 50.

16. Engle, R. F. and Granger G. W. J. (1987). Co-integration and Error Correction: Representation, Estimation and Testing:. Econometrica, 55, 251-276.

17. Guna Raj Bhatta (2013), "Remittance and Trade Deficit Nexus in Nepal: A VECM Approach". Nepal Rastra Bank, Working Paper Research Department: Serial Number: NRB/WP/14NRB.

18. Ibrahim, Aand Ahmed E. (2017). The Determinants of Aggregate Demand Function of Sudan: Business Economic Journal, 8(3), 1-7.

19. Johansen S. (1991). Estimation and Hypothesis Testing of Cointegrating Vectors in Gaussian Vector Autoregressive Models: Econometrica, 59, 1551-1580.

20. Johansen, S., Juselius, K. (1990). Maximum Likelihood Estimation and Inference on Cointegration with Applications to the Demand for Money: Oxford Bulletin of Economics and Statistics, 52, 169-210.

21. Karan, Singh Thagunna and Sanjanya Acharya (2013). Empirical Analysis of remittances inflow: The Case of Nepal: International Journal of Economics and Finance, 3(2), 337-344.

22. Khair-Uz, Zaman and Nazakat Ali (2005). Workers' Remittances and Import Demand in Pakistan: The Philippine Review of Economics, XLII (2):127-136.

23. Khurram, Ashfaq Baluch and Syed Kalim H. Bukhari (2012). Price and Income Elasticity of Imports: The case of Pakistan: State Bank of Pakistan (SBP), Working Paper Series, No.48.

24. Kreishan, F. (2007. Estimating an Import Function for Jordan: A Cointegration Analysis: Dirasat, Administrative Sciences, 34(2), 407-415.

25. M., Sayed Abu-Elseoud (2014). Do Remittances Matter for Egyptian Economy?: International Journal of Applied Operational Research, 4(1), 1-26.

26. Majeed, H. (2007). Estimating long-run elasticities of Jordanian import demand function: 1980-2004: an application of dynamic OLS: Applied Economics and International Development, 7(2), 171182. 
27. Mugableh, M. Ibrahim (2017). Estimating Elasticity Function of Jordanian Aggregate Import Demand: Applied Economics and Finance, 4(2), 33-37.

28. Munir, K.; Naeem-ur-Rehman; Yahya B.; Badshah N.; Tariq R.; and Akhtar A. (2007). Remittances As A Determinant of Import Function (An Empirical Evidence from Pakistan): Sarhad J. Agric., 23(4), 1187-1190.

29. Narayan, S. and Narayan P. K. (2005). An Empirical Analysis of Fiji's Import Demand Function; Journal of Economic Studies, 32(2), 158-168.

30. Nazif, Durmaz and Jaehyuk Lee (2015) An Empirical Analysis of Import Demand Function for Turkey: An ARDL Bounds Testing Approach: The Journal of Developing Areas, 49(4), 2015-229.

31. N'guessan, Bi Zambe, and Yaoxing Yue (2010). An Econometric Estimation of Import Demand Function for Cote D'Ivoire: International Journal of Business and Management, 5(2), 77-84.

32. Pesaran, M. H; Shin, Y, and Smith, R. J. (2001). Bounds Testing Approaches to the Analysis of Level Relationships: Journal of Applied Econometrics, 16, 289-326.

33. Soana, Jaupllari (Teka), and Olta Zoto (2013). Assessment of Demand for Imports through the VECM Model; Journal of Knowledge Management, Economics and Information Technology, 3(6), 1-17.

34. Sulaiman, D. Muhammad and Saba Zafar (2016). Determinants of Import Demand Functions of Pakistan: An ARDL Bound Testing Approach: International Journal of Business, 3(9), 113-121.

35. Wang, Yi-Hsien and Jun-De Lee (2012). Estimating the Import Demand Function for China: Economic Modeling, 29, 2591-2596.

36. Ziad, Mohammed Abu-Lila (2014). Price and Income Elasticities of International Trade: Case of Jordan". International Journal of Economics and Finance, 6(10), 250-258.

37. Zhou, Yan and Smile Dube (2011). Import Demand Functions: Evidence from CIBs: Journal of Economic Development, 36(4), 7396. 